\title{
PENGARUH PEMBERDAYAAN DAN KEPERCAYAAN TERHADAP TANGGUNG JAWAB KEPALA SEKOLAH DASAR NEGERI KECAMATAN PULOGADUNG JAKARTA TIMUR
}

\author{
THE EFFECT OF EMPOWERMENT AND TRUST TO PRINCIPAL \\ RESPONSIBILITIES OF PRIMARY STATE SCHOOL \\ IN PULOGADUNG, EAST JAKARTA DISTRICT
}

\author{
Theresia Supartinah *
}

\begin{abstract}
This study provides information on the effect of empowerment and trust in the responsibility of the principal at SDN Pulogadung, East Jakarta. The method used in this research is the survey method using a quantitative approach, and explain the causal relationship with path analysis. Data were collected by questionnaire. The target population of this study amounted to 92 principals of all Heads of State Primary School in District of Pulogadung in East Jakarta. In this study a sample set of 75 people, using simple random sampling. Results from this study indicate that: (1) there is a positive direct effect of the empowerment to responsibility, (2) there is a positive direct effect of trust to the responsibility, and (3) there is a positive direct effect of trust to empowerment.
\end{abstract}

Keywords: responsibility, empowerment, trust

\section{PENDAHULUAN}

Dalam UU Sistem Pendidikan Nasional Nomor 20 Tahun 2003 pasal empat ayat satu berbunyi, "Pendidikan diselenggarakan secara demokratis dan berkeadilan serta tidak diskriminatif dengan menjunjung tinggi hak asasi manusia, nilai keagamaan, nilai kultural, dan kemajemukan bangsa. Pendidikan memiliki fungsi yang hakiki dalam mempersiapkan sumber daya manusia (SDM) yang berkualitas yang akan menjadi pelaku utama dalam menjalankan berbagai fungsi dalam berbagai bidang kehidupan. Berjalannya sistem pendidikan tidak boleh dibiarkan dari perubahan yang terjadi dalam berbagai bidang kehidupan (wawancara dengan Kasi Dikdas Kecamatan Pulogadung).

Tantangan, kendala, dan masalah-masalah yang dihadapi oleh pendidikan tidak semata-mata bersumber dari sistem pendidikan secara internal, namun yang terbanyak adalah tantangan eksternal atau tantangan yang berasal dari luar sistem pendidikan. Perkembangan dunia yang cepat berubah menuntut dan mensyaratkan kemampuan penguasaan pendidikan yang lebih cepat. Kompleksitas dunia yang terus meningkat pun menuntut kemampuan yang sesuai untuk menganalisis setiap situasi secara logis dan memecahkan masalah secara kreatif.

Dengan keadaan dan kemampuan yang terbatas, Dinas Pendidikan Dasar berupaya untuk meningkatkan kualitas sumber daya manusia dalam bidang pendidikan. Hal ini terlihat dalam berbagai upaya dalam melakukan perbaikanperbaikan, pembinaan, pembenahan manajemen, pengadaan buku pelajaran, alat bantu mengajar, perbaikan sarana fisik sekolah, pengembangan bakat para peserta didik dan menjalin kerjasama dengan masyarakat setempat beserta jajaran pemerintah. Meskipun patut menjadi catatan bahwa perkembangan yang terjadi di lapangan belumlah

* Kepala Sekolah SDS St. Fransiskus III 
maksimal sesuai dengan yang diharapkan.

Beberapa fakta yang dipaparkan di atas mengindikasikan bahwa tanggung jawab kepala sekolah masih rendah dengan faktor-faktor antara lain: (1) Suasana kerja/iklim kerja di sekolah yang kurang kondusif, dan tidak mendukung pencapaian tujuan visi dan misi secara efektif, (2) Pengawas yang jarang melakukan pembinaan kepada kepala sekolah sehingga pemberdayaan dan kepercayaan yang dimiliki tidak mendukung untuk melaksanakan tugas dan pencapaian visi misi sekolah, (3) Pengawas jarang memberikan kepercayaan, inovasi, kreativitas, dan bimbingan karir sehingga para kepala sekolah tidak terdorong untuk aktif, kreatif, inovatif, dan efektif dalam bekerja, (4) Tidak dilaksanakannya fungsi-fungsi manajemen secara optimal oleh pengawas untuk mendorong kepala sekolah melaksanakan tugasnya secara profesional dan meningkatkan rasa tanggung jawab, (5) Keterampilan yang kurang memadai dalam mengupayakan pengembangan sekolah sehingga tidak mendukung pencapaian tujuan sekolah secara efektif, (6) Motivasi kerja yang dimiliki tidak menjadi motor penggerak terbentuknya disiplin diri (self discipline) sehingga tidak mendukung peningkatan tanggung jawab, dan (7) Kompetensi yang dimiliki kepala sekolah masih terbatas sehingga tidak mendukung komitmennya dalam melaksanakan tugas-tugas secara profesional. Dari beberapa faktor yang mempengaruhi tanggung jawab kepala sekolah, dibatasi hanya pada pengaruh pemberdayaan dan kepercayaan terhadap tanggung jawab kepala SD Negeri Kecamatan Pulogadung, Jakarta Timur.

\section{Tanggung Jawab}

Menurut Boddy (2012:321) berpendapat bahwa "responsibility refers to a person's duty to meet the expectations others have of them". Tanggung jawab mengacu pada tugas seseorang untuk memenuhi harapan orang lain dari mereka. Pelaksanaan manajemen yang baik dalam suatu organisasi adalah adanya pemberian wewenang atau delegasi kepada setiap orang untuk menyelesaikan pekerjaan, sesuai kewajibannya dengan penuh tanggung jawab. Dalam melaksanakan tugasnya, seorang pemimpin tidak bekerja seorang diri. Ia akan dibantu oleh staf atau bawahannya. Oleh karena itu, keduanya harus menjalin hubungan dengan baik dan harmonis agar tujuan organisasi yang ingin dicapai dapat terwujud. Selanjutnya Menurut Mejia (2012:257), tanggung jawab sebagai "responsibility the manager's duty to perform assigned tasks". Tanggung jawab adalah tugas manajer untuk melakukan tugas yang diberikan. Tanggung jawab seorang manajer tidak saja menyangkut penataan manajemen organisasi, tetapi harus bertanggung jawab terhadap semua unsur yang menunjang terhadap kelangsungan organisasi yang dipimpinnya. Hal ini menyangkut bawahan, para pemegang kebijakan, para relasi dan konsumen termasuk dalam bersikap dan berperilaku. Prinsip dari tanggung jawab menurut Mullins (2010:609), "the principle of responsibility is the responsibility of the superior for the acts of the subordinate is absolute". Prinsip dari tanggung jawab adalah tanggung jawab untuk menjadi lebih unggul dalam kerja sebagai seorang bawahan itu merupakan suatu keharusan.

Menurut Certo (2012:274) mengatakan, "responsibility is the obligation to perform assigned activities". Tanggung jawab adalah kewajiban untuk melakukan kegiatan yang ditugaskan. Tanggung jawab tersebut, sepenuhnya berlaku bagi keseluruhan struktur organisasi terutama bagi seorang pimpinan. Tanggung jawab yang disertakan tersebut hanya merupakan ciptaan sementara. Hal ini dilakukan karena bawahan menerima tugas tersebut dan oleh karena keadaan tertentu sehingga pimpinan harus mendelegasikan wewenangnya. Yang dimaksud dengan wewenang (outhority) adalah hak melakukan sesuatu atau memerintah orang lain untuk melakukan atau tidak 
melakukan sesuatu agar tujuan tertentu tercapai. Salah satu prinsip organisasi penting adalah bahwa individu-individu seharusnya diberi wewenang untuk melaksanakan tanggung jawabnya. Pemberian wewenang untuk melaksanakan tanggung jawab ini tetap harus disertai dengan pengawasan, karena bagaimanapun tanggung jawab seorang manajer selalu lebih besar dari wewenangnya. Hal inilah yang merupakanciri delegasi.

Berdasarkan uraian di atas, dapat disintesiskan bahwa tanggung jawab adalah suatu proses penyelesaian pekerjaan secara tepat dan efisien, dengan indikator: (1) pencapaian target, (2) realisasi tujuan, (3) kualitas pekerjaan, (4) efisiensi pekerjaan, (5) tingkat produktivitas.

\section{Pemberdayaan}

Menurut Uhl-Bien (2014:262) mendefinisikan pemberdayaan sebagai, "empowerment involves sharing power, information, and rewards with employees to make decisions and solve problems in their work". Pemberdayaan melibatkan berbagai kekuasaan, informasi, dan manfaat dengan karyawan untuk membuat keputusan dan memecahkan masalah dalam pekerjaan mereka. Melalui usaha pemberdayaan pegawai sebagai bagian dari salah satu unsur sumber daya organisasi, dalam jangka panjang, organisasi akan mampu secara optimal memanfaatkan sumber daya manusianya. Sedangkan menurut Luthans (2012:368), pemberdayaan didefinisikan sebagai, "empowerment the process of giving individuals and teams the resources, information, and authority they need to develop ideas and effectively implement them". Pemberdayaan merupakan proses pemberian individu dan tim sumber daya, informasi, dan otoritas yang mereka butuhkan untuk mengembangkan ide-ide dan menerapkannya secara efektif.

Menurut Gibson (2012:508) mengemukakan, "empowerment giving employees permission to make decisions to complete workloads on time". Pemberdayaan memberikan kesempatan bagi karyawan untuk membuat keputusan dalam menyelesaikan beban kerja tepat pada waktunya. Pemberdayaan tidak cukup hanya dengan membangun kemampuan dan memberinya peluang untuk berbuat, tetapi pemberdayaan pun berkaitan dengan nilai. Pemberdayaan memerlukan tingkat kejujuran yang tinggi, keterbukaan, dan integritas pada manajemen puncak. Dengan demikian, pemberdayaan bukan sekedar pemberian delegasi dari pimpinan kepada pegawai di bawahnya, tetapi lebih pada sistem nilai dalam organisasi yang dianut. Menurut Annie McKee (2012:27), "empowerment trusting employees to make decisions and to take responsibility for their decisions and actions". Pemberdayaan mempercayaikan kepada karyawan untuk membuat keputusan dan mengambil tanggung jawab atas keputusan dan tindakan mereka. Berkaitan dengan pemberdayaan Colquitt menyatakan sebagai berikut, "there are four concepts of empowerment, which are particularly important : (1) Meaningfulness reflects the values of a work goal or purpose, relative to a person's own ideals and passions, (2) Selfdetermination reflects a sense of choice in the initiation and continuations of works tasks, (3) Competence reflects a person's belief in his or her capability to perform work tasks successfully, and (4) Impact reflects the sense that a person's actions "Make a difference" that progress is being made toward fulfilling some important purpose." Menurut Colquitt ada empat konsep penting dalam pemberdayaan, yaitu (1) "meaningfulness" menggambarkan nilai atau makna dari tujuan pekerjaan sesuai dengan cita-cita dan keinginan seseorang, (2) "selfdetermination" kepekaan untuk menentukan suatu pilihan pada awal dan perkembangan dari pekerjaan, (3) "competence" keyakinan seseorang akan kemampuannya untuk melaksanakan tugas dengan optimal, (4) "impact" keyakinan seseorang bahwa tindakannya berpengaruh demi tercapainya beberapa tujuan yang penting. 
Berdasarkan uraian di atas, dapat disintesiskan bahwa pemberdayaan adalah pemberian otoritas kepada pegawai untuk membuat keputusan dalam menyelesaikan pekerjaan, dengan indikator: (1) keleluasaan dalam pemecahan masalah, (2) melakukan inovasi (3) berinisiatif, (4) mengemukakan ide, dan (5) pengembangan diri.

\section{Kepercayaan}

Colquitt mendefinisikan kepercayaan (2011:219), "as the willingness to be vilnerable to an authority based on positive expectations about the authority's actions and intention", sebagai kesediaan untuk menerima kritikan terhadap otoritas yang didasarkan pada harapan-harapan positif tentang orotiritas dan niat. Pendapat senada disampaikan oleh Robbins (2013:387) bahwa kepercayaan adalah "a positive expectation that another will not act opportunistically, through words, actions, or decisions". Harapan positif bahwa orang lain tidak akan berbuat oportunistik melalui perkataan, tindakan, atau keputusan.

Richard mengatakan (2009:693) "where as transformational leaders build trust by showing commitment to flolowers' needs over self-interest, some charismatic leaders are not beyond taking credit for others accomplishments or exaggerating their expertise." Pemimpin transformasional membangun kepercayaan dengan menunjukkan komitmen terhadap bawahannya di atas kepentingan pribadi, beberapa pemimpin karismatik tidak memberi pinjaman untuk orang lain terkait dengan prestasi yang dicapai oleh seseorang. Menurut George and Jones (2012:75) mengungkapkan, "an expression of confidence in another person or group of people that you will not be put at risk, harmed or injured by their actions". Kepercayaan adalah ungkapan keyakinan terhadap orang lain atau kelompok orang yang tidak akan berisiko, dirusak, atau dilukai oleh tindakan-tindakan mereka.

Dalam membangun kepercayaan menurut Kreitner (2012:318) dapat dilakukan seperti, "commucation keeps team members and employees inforced by explaining policies and decision and providing accurate feedback." Komunikasi menjaga anggota tim dan pegawai tetap terinformasikan dengan menjelaskan kebijakkan-kebijakkan dan keputusan yang menyediakan umpan balik yang tepat bagi pegawai. Pendapat yang hampir sama dikemukakan oleh Suzanne (2009:33) bahwa, "how do we define trust? Trust is a multifaceted concept that captures one's faith or belief in the integrity or reability of another person or thing. Simply put, trust means confidence. When you trust people, you have convidence in them in their integrity and in their abilities." Menurut Suzanne, kepercayaan adalah sebuah konsep multifaset yang menangkap iman seseorang atau kepercayaan pada integritas dari orang lain. Sederhananya, kepercayaan berarti keyakinan. Ketika anda mempercayai orang lain, anda memiliki tingkat kepercayaan dalam integritas dan kemampuan mereka.

Berdasarkan deskripsi konsep di atas, dapat disintesiskan bahwa kepercayaan adalah keyakinan timbal balik terhadap orang lain atau kelompok lain untuk tidak akan bertindak dan mengambil keuntungan untuk diri sendiri dari kesempatan yg ada tanpa berpegang pada prinsip tertentu (oportunistik) melalui perkataan, tindakan, perilaku atau keputusan dengan indikator: (1) memiliki integritas, (2) konsisten, dan (3) bersikap terbuka.

\section{METODOLOGI PENELITIAN}

Penelitian ini bertujuan untuk menguji pengaruh langsung; (1) pemberdayaan terhadap tanggung jawab, (2) kepercayaan terhadap tanggung jawab, dan (3) pemberdayaan terhadap kepercayaan. Penelitian menggunakan metode survey dengan 
pendekatan teknik analisis jalur. Penelitian dilaksanakan di SD Negeri Kecamatan Pulogadung, Jakarta Timur. Populasi terjangkau penelitian ini sejumlah 92 kepala sekolah. Sampel penelitian sebayak 75 orang. Analisa data untuk pengujian hipotesis akan dilakukan dengan menggunakan teknik analisis jalur, yaitu teknik yang diterapkan untuk menjelaskan pengaruh antara variabel-variabel penelitian. Sebelum dilaksanakan analisis jalur, uji signifikan regresi dan uji linearitas regresi sebagai prasyarat uji statistik dilakukan pengujian penormalan data dari masing-masing variabel penelitian dengan Uji-Liliefors, Statistik inferensial digunakan untuk menguji hipotesis tentang pengaruh antar variabel dengan menggunakan tehnik analisis jalur.

\section{HASIL PENELITIAN DAN PEMBAHASAN \\ Pengaruh Pemberdayaan terhadap Tanggung Jawab}

Dari hasil pengujian hipotesis pertama dapat disimpulkan bahwa terdapat pengaruh langsung positif pemberdayaan terhadap tanggung jawab dengan nilai koefisien korelasi sebesar 0,552 dan nilai koefisien jalur sebesar 0,398. Ini memberikan makna motivasi berpengaruh langsung terhadap efektivitas kerja. Boddy (2012:321) berpendapat bahwa "responsibility refers to a person's duty to meet the expectations others have of them". Tanggung jawab mengacu pada tugas seseorang untuk memenuhi harapan orang lain dari mereka. Pelaksanaan manajemen yang baik dalam suatu organisasi adalah adanya pemberian wewenang atau delegasi kepada setiap orang untuk menyelesaikan pekerjaan, sesuai kewajibannya dengan penuh tanggung jawab. Selanjutnya Menurut Mejia (2012:257), tanggung jawab sebagai "responsibility the manager's duty to perform assigned tasks". Tanggung jawab adalah tugas manajer untuk melakukan tugas yang diberikan. Tanggung jawab seorang manajer tidak saja menyangkut penataan manajemen organisasi, tetapi harus bertanggung jawab terhadap semua unsur yang menunjang terhadap kelangsungan organisasi yang dipimpinnya. Hal ini menyangkut bawahan, para pemegang kebijakan, para relasi dan konsumen termasuk dalam bersikap dan berperilaku. Selanjutnya Menurut Mejia (2012:257), tanggung jawab sebagai "responsibility the manager's duty to perform assigned tasks". Tanggung jawab adalah tugas manajer untuk melakukan tugas yang diberikan. Tanggung jawab seorang manajer tidak saja menyangkut penataan manajemen organisasi, tetapi harus bertanggung jawab terhadap semua unsur yang menunjang terhadap kelangsungan organisasi yang dipimpinnya. Hal ini menyangkut bawahan, para pemegang kebijakan, para relasi dan konsumen termasuk dalam bersikap dan berperilaku. Mullins (2010:609) menjelaskan, "the principle of responsibility is the responsibility of the superior for the acts of the subordinate is absolute". Prinsip dari tanggung jawab adalah tanggung jawab untuk menjadi lebih unggul dalam kerja sebagai seorang bawahan itu merupakan suatu keharusan.

Hasil penelitian ini senada dengan pendapat beberapa ahli diantaranya menurut Mullins (2011:465) yang mengatakan, "empowerment where employees are allowed greater freedom, autonomy and self-control over their work, and the responsibility for decision-making", pemberdayaan adalah tempat bagi karyawan yang diberi kebebasan lebih besar, otonomi dan kontrol diri atas pekerjaan mereka, dan tanggung jawab untuk pengambilan keputusan.

Menurut Armstrong (2012:150) mengatakan, "in practice, management and team leaders are often entirely responsible for planning and control, leaving the worker responsible for execution. To a degree, this is inevitable, but one of the aims of job design is often to extend the responsibility of workers into the functions of planning and control. This can involve 
empowerment - giving individuals and teams more responsibility for decision making and ensuring that they have the training, support and guidance to exercise that responsibility properly." Dalam prakteknya, manajemen dan pemimpin tim sering sepenuhnya bertanggung jawab untuk perencanaan dan pengendalian, meninggalkan pekerja yang bertanggung jawab untuk mengeksekusi. Hal ini tidak bisa dihindari, tetapi salah satu tujuan dari desain pekerjaan sering untuk memperluas tanggung jawab pekerja ke dalam fungsi perencanaan dan pengendalian. Dengan demikian, dapat melibatkan pemberdayaan - memberikan individu dan tim yang lebih bertanggung jawab atas pengambilan keputusan dan memastikan bahwa mereka memiliki pelatihan, dukungan dan bimbingan untuk melaksanakan tanggung jawab itu benar.

Sedangkan menurut Snell (2013:212), "in helping individuals plan their careers, it is important for organizations to recognize that younger employees today seek meaningful training assignments that are interesting and involve challenge, responsibility, and a sense of empowerment." Dalam membantu individu merencanakan karir mereka, penting bagi organisasi untuk mengakui bahwa karyawan yang lebih muda saat ini mencari tugas pelatihan yang bermakna yang menarik dan melibatkan tantangan, tanggung jawab, dan rasa pemberdayaan. Pemberdayaan mengandung makna adanya perubahan pada diri seseorang dari ketidakmampuan menjadi mampu, dari tidak memiliki kewenangan menjadi memiliki kewenangan, dari ketidakmampuan untuk bertanggung jawab menjadi mampu tanggung jawab terhadap suatu yang dikerjakan. Pemberdayaan berarti memberikan kesempatan kepada seseorang untuk melakukan suatu aktivitas dengan kewenangan dan tanggung jawab yang dimilikinya.

\section{Pengaruh Kepercayaan terhadap Tanggung Jawab}

Dari hasil pengujian hipotesis kedua dapat disimpulkan bahwa terdapat pengaruh langsung positif kepercayaan terhadap tanggung jawab dengan nilai koefisien korelasi sebesar 0,567 dan nilai koefisien jalur sebesar 0,421. Ini memberikan makna kepercayaan berpengaruh langsung terhadap tanggung jawab. Colquitt mendefinisikan kepercayaan (2011:219), "as the willingness to be vilnerable to an authority based on positive expectations about the authority's actions and intention", sebagai kesediaan untuk menerima kritikan terhadap otoritas yang didasarkan pada harapan-harapan positif tentang orotiritas dan niat. Pendapat senada disampaikan oleh Robbins (2013:387) bahwa kepercayaan adalah "a positive expectation that another will not act opportunistically, through words, actions, or decisions". Harapan positif bahwa orang lain tidak akan berbuat oportunistik melalui perkataan, tindakan, atau keputusan. George and Jones (2012:75) mengungkapkan, "an expression of confidence in another person or group of people that you will not be put at risk, harmed or injured by their actions". Kepercayaan adalah ungkapan keyakinan terhadap orang lain atau kelompok orang yang tidak akan berisiko, dirusak, atau dilukai oleh tindakan-tindakan mereka. Dalam membangun kepercayaan menurut Kreitner (2012:318) dapat dilakukan seperti, "commucation keeps team members and employees inforced by explaining policies and decision and providing accurate feedback." Komunikasi menjaga anggota tim dan pegawai tetap terinformasikan dengan menjelaskan kebijakkan-kebijakkan dan keputusan yang menyediakan umpan balik yang tepat bagi pegawai. Suzanne (2009:33) bahwa, "how do we define trust? Trust is a multifaceted concept that captures one's faith or belief in the integrity or reability of another person or thing. Simply put, trust means confidence. When you trust people, you have convidence in them in their integrity and in their abilities." Menurut Suzanne, kepercayaan adalah sebuah konsep multifaset yang menangkap iman seseorang atau kepercayaan pada 
integritas dari orang lain. Sederhananya, kepercayaan berarti keyakinan. Ketika anda mempercayai orang lain, anda memiliki tingkat kepercayaan dalam integritas dan kemampuan mereka.

Hasil penelitian ini senada dengan pendapat beberapa ahli di antaranya adalah menurut Snell (2013:717) mengemukakan, "trust is a fragile component of an alliance and is reflected in the degree to which parties are comfortable sharing information and decision-making responsibilities". Kepercayaan adalah komponen rapuh dari aliansi dan tercermin dalam sejauh mana pihak berbagi informasi nyaman dan tanggung jawab dalam pengambilan keputusan. Pada sebuah level tim, harus ada level kepercayaan yang tinggi di antara anggota tim. Para anggota harus percaya tentang integritas, karakter dan kemampuan mereka. Sebagaimana kita sadari, kepercayaan membutuhkan waktu yang lama untuk dibangun dan dapat berada dalam keadaan bahaya satu tindakan ceroboh. Suasana kepercayaan dalam sebuah tim dapat saja sangat bergantung pada persepsi anggota dari kepercayaan manajemen atas kelompok secara keseluruhan dan sehingga level kepercayaan manajemen itu dapat berfungsi untuk meningkat atau menghilang dari kepercayaan anggota.

Menurut Scarborough (2012:659), "trust workers to do their jobs. Once workers are trained to do their jobs, owners must learn to trust them to assume responsibility for their jobs. After all, they are the real experts; they face the problems and challenges every day." Percaya kepada pekerja-pekerja untuk melakukan pekerjaan mereka. Setelah pekerja dilatih untuk melakukan pekerjaan mereka, pemilik harus belajar untuk mempercayai mereka untuk bertanggung jawab atas pekerjaan mereka. Setelah semua itu, mereka menjadi benar-benar ahli; mereka menghadapi masalah dan tantangan setiap hari. Organisasiorganisasi yang menghargai kejujuran, keterbukaan dan proses kolaborasi karyawan dengan keterlibatan karyawan yang tinggi akan lebih cenderung merangsang budaya mempercayai daripada organisasi yang tidak. Sesuai dengan pendapat Robbins (2011:478) yang mengatakan, "employees have to trust managers to treat them fairly, and managers have to trust employees to conscientiously fulfill their responsibilities". Karyawan harus mempercayai manajer yang memperlakukan mereka dengan adil, dan manajer harus percaya pada karyawan yang sungguh-sungguh memenuhi tanggung jawab mereka.

\section{Pengaruh Pemberdayaan terhadap Kepercayaan}

Dari hasil pengujian hipotesis ketiga dapat disimpulkan bahwa terdapat pengaruh langsung positif pemberdayaan terhadap kepercayaan dengan nilai koefisien korelasi sebesar 0,366 dan nilai koefisien jalur sebesar 0,366. Ini memberikan makna pemberdayaan berpengaruh langsung terhadap kepercayaan. Uhl-Bien (2014:262) mendefinisikan pemberdayaan sebagai, "empowerment involves sharing power, information, and rewards with employees to make decisions and solve problems in their work". Pemberdayaan melibatkan berbagai kekuasaan, informasi, dan manfaat dengan karyawan untuk membuat keputusan dan memecahkan masalah dalam pekerjaan mereka. Melalui usaha pemberdayaan pegawai sebagai bagian dari salah satu unsur sumber daya organisasi, dalam jangka panjang, organisasi akan mampu secara optimal memanfaatkan sumber daya manusianya. Sedangkan menurut Luthans (2012:368), pemberdayaan didefinisikan sebagai, "empowerment the process of giving individuals and teams the resources, information, and authority they need to develop ideas and effectively implement them". Pemberdayaan merupakan proses pemberian individu dan tim sumber 
daya, informasi, dan otoritas yang mereka butuhkan untuk mengembangkan ide-ide dan menerapkannya secara efektif.

Hasil penelitian ini senada dengan pendapat beberapa ahli di antaranya adalah menurut DuBrin (2012:353), "a key component of empowerment is the leader's acceptance of the employee as a partner in decision making. Because the team member's experience and information are regarded as equal to those of the leader, he or she shares control. Both the leader and team member must agree on what is to be accomplished. The partnering approach to empowerment builds trust between the employee and the leader." Sebuah komponen kunci dari pemberdayaan adalah penerimaan pemimpin dari karyawan sebagai mitra dalam pengambilan keputusan. Karena pengalaman dan informasi anggota tim dianggap sama dengan orang-orang dari pemimpin, ia berbagi kontrol. Kedua anggota pimpinan dan tim harus sepakat tentang apa yang akan dicapai. Pendekatan kemitraan untuk pemberdayaan membangun kepercayaan antara karyawan dan pemimpin. Menurut Robbins (2012:392), "I shape my employees' behavior by earning their trust, truly listening to what they say, understanding their perspective on things, and empowering them to be successful". Saya membentuk perilaku karyawan saya 'dengan mendapatkan kepercayaan mereka, benar-benar mendengarkan apa yang mereka katakan, memahami perspektif mereka pada hal-hal, dan memberdayakan mereka untuk menjadi sukses. Sependapat dengan Annie McKee (2012:27) yang mengatakan, "empowerment trusting employees to make decisions and to take responsibility for their decisions and actions". Pemberdayaan adalah mempercayai karyawan untuk membuat keputusan dan mengambil tanggung jawab atas keputusan dan tindakan mereka.

\section{PENUTUP}

Kesimpulan: Berdasarkan hasil pengujian hipotesis dan dan pembahasan yang telah dikemukakan diperoleh kesimpulan penelitian sebagai berikut: (1) Pemberdayaan berpengaruh langsung positif terhadap tanggung jawab, hal ini menunjukkan bahwa pemberdayaan yang tinggi akan meningkatkan tanggung jawab, semakin tinggi pemberdayaan maka akan semakin baik tanggung jawab kepala SD Negeri Kecamatan Pulogadung, Jakarta Timur. (2) Kepercayaan berpengaruh langsung positif terhadap tanggung jawab, hal ini menunjukkan bahwa kepercayaan yang tinggi akan meningkatkan tanggung jawab, semakin tinggi kepercayaan maka akan semakin baik tanggung jawab kepala SD Negeri Kecamatan Pulogadung, Jakarta Timur. (3) Pemberdayaan berpengaruh langsung positif terhadap kepercayaan, hal ini menunjukkan bahwa pemberdayaan yang tinggi akan meningkatkan kepercayaan, pengakuan atas kerja kepala sekolah dan pemberian apresiasi atas hasil kerja kepala sekolah.

Saran: Berdasarkan kesimpulan dan implikasi di atas, beberapa saran yang dapat disampaikan peneliti adalah sebagai berikut: (1) Dengan kepercayaan yang tinggi dari dalam diri kepala sekolah maka akan menjaga suasana kondusif di tempat kerja, semangat dalam beraktivitas, akrab dengan rekan kerja, melaksanakan tugas dengan baik, siap menerima kritik dan saran dari teman sejawat/guru, kepala sekolah, siswasiswa, dan staf sekolah yang lain, tanggung jawab dalam mengembangkan sekolah dan melaporkan hasil kegiatan kepada atasan, serta tegas dalam bersikap. (2) Peningkatan pemberdayaan perlu dilakukan karena dengan mampu berinovatif, berkreasi, keleluasaan dalam pemecahan masalah, melakukan inovasi, berinisiatif di barengi dengan tanggung jawab yang baik. (3) Tanggung jawab yang optimal dapat dicapai karena adanya dukungan dari organisasi atau sekolah tempat bekerja. Sekolah yang 
kondusif lingkungan internal sekolah dapat menunjang kualitas pekerjaan. Oleh karena itu tidak ada kata lain selain kepala sekolah harus meningkatkan pemberdayaan dan memiliki kepercayaan yang tinggi dalam berupaya mendapatkan tanggung jawab secara optimal. 


\section{DAFTAR RUJUKAN}

Armstrong, Michael, Armstrong's Handbook of Human Resource Management Practice. London: Kogan Page Limited,12th Edition, 2012.

Boddy, David, Management: An Introduction. Essex: Pearson Education Limited,4th Edition, 2012.

Colquitt, Jason, Jeffery Lepine, Organizational Behavior: Improving Performance And Commitment In The Workplace. New York: Mcgraw-Hill, 2011.

Certo, Samuel C, Modern Management: Concepts And Skills. New Jersey: Prentice Hall,12th Edition, 2012.

DuBrin, Andrew J., Essentials of Management. Mason: Cengage Learning,Ninth Edition, 2012.

Gomez, Mejia, Luis R, David B. Balkin, Management. New Jersey: Prentice Hall, 2012.

Gibson, James L, Organizations: Behavior, Structure, Processes. New York: Mc Graw-Hill, 2012.

George, Jennifer M., Gareth R. Jones, Understanding And Managing Organizational Behavior. New Jersey: Pearson Press,Sixth Edition, 2012.

Jason A. Colquit., Jeffery A. LePine, dan Michael J. Wesson, Orgnanizational Behavior, Improving Performance and Commitment in the Workplace. New York: Mc Graw-Hill Companies, Inc, 2009.

Kreitner dan Kinicki, Organizational Behavior, Ninth Edition. New York: Mc Graw Hill, 2010.

Luthans, Fred, Jonathan P. Doh, International Management: Culture, Strategy, and Behavior. New York:McGraw-Hill, 8th Edition, 2012.

McKee, Annie, Management: A Focus On Leaders. New Jersey:Prentice Hall, 2012.

Mullins, Laurie J. Management and Organisational Behaviour. Essex: Pearson Education Limited,Ninth Edition, 2010.

Mullins, Management and Organizational Behaviour. Boston: Mc Graw-Hill, 2011.

McKee, Annie, Management: A Focus On Leaders. New Jersey: Prentice Hall, 2012.

Richard L Luges, Robert C Cinnett, Gordon J. Curphy, Leadership Enchancing The Lessons of Experience. New York: Mc Graw Hill, 2009.

Robbins, Organizational Behavior. Boston: Mc Graw-Hill, 2011. 
Robbins, Stephen P., Mary Coulter, Management. New Jersey: Prentice Hall,11 th Edition, 2012.

Robbins, Stephen P., Timothy Judge, Organizational Behavior. New Jersey: Pearson International Edition, 13 ${ }^{\text {th }}$ Edition, 2013.

Susanze C De Jananasz. Karen O. Dowd. Beth Z. Schnelder Interpersonal Skill in Organizations. New York: Mc Graw Hill, 2009.

Scarborough, Norman M, Effective Small Business Management : An Entrepreneurial Approach. New Jersey: Pearson Education, Inc, 10th Edition, 2012.

Snell, Scott and George Bohlander, Managing Human Resources. New York: SouthWestern, Cengage Learning, 16th edition, 2013.

Uhl-Bien, Mary, John R. Schermerhorn, Jr. and Richard N. Osborn, Organizational Behavior: Experience Grow Contribute. 13th edition New Jersey: John Wiley \& Sons, 2014. 